\title{
PENERAPAN PROTOTYPE MODEL UNTUK SISTEM INFORMASI E-PAYMENT RUSUNAWA BERBASIS ANDROID
}

\author{
Yusnia Budiarti ${ }^{1)}$ \\ Teknik Informatika, STMIK Nusa Mandiri Jakarta \\ Email: yusnia.ybi@nusamandiri.ac.id \\ Arief Nashuha Dhali' \\ Sistem Informasi, STMIK Nusa Mandiri Jakarta \\ Email: Nashuha.sukses@gmail.com
}

\begin{abstract}
ABSTRAKSI
Informasi yang diberikan Pada Rumah Susun Sewa (Rusunawa) pada umumnya masih dilakukan secara manual dalam penyampaian informasi pengelolaannya, seperti informasi pembayaran, pengumuman, pemberian peringatan atas keterlambatan pembayaran masih dilakukan dari pintu ke pintu. Hal ini mengakibatkan proses penyampaian informasi yang kurang efektif, seperti untuk memperoleh informasi para penghuni harus datang ke pihak pengelola langsung, para penghuni yang banyak aktivitas kerja kurang mendapatkan informasi yang jelas apabila ada pengumuman, informasi yang dilakukan dari pintu ke pintu tidak efektif karena apabila penghuni tidak ditempat maka penghuni tidak mendapat keterangan dengan jelas. Demikian pula untuk proses penagihan pembayaran, penghuni Sebagian besar para pekerja terkesan sulit meluangkan waktu untuk melakukan pembayaran secara tepat waktu. Dengan melihat beberapa masalah diatas maka dibuatlah sistem informasi e-payment berbasis Android yang bisa diakses oleh penghuni kapan saja dan dimana saja untuk memperoleh informasi tentang pembayaran serta melakukan pembayaran sewa..Dengan demikian akan lebih efektif dan efisien dalam penyampaian informasi oleh admin kepada penghuni. Sistem akan mengimplementasikan model prototype untuk merancang sistem dan sistem akan dirancang pada platform android sehingga mudah digunakan dimana saja dan kapan saja
\end{abstract}

Kata kunci : pembayaran elektronik, model prototipe, Android

\section{ABSTRACT}

Information provided in Rental Flats in general are still done manually in the delivery of management information, such as payment information, announcements, giving warnings for late payments still being made door-to-door. This results in an ineffective information delivery process, such as to obtain information that residents must come to the management directly, residents who have a lot of work activities lack clear information if there is an announcement, information carried out from door to door is ineffective because if the occupants not in place, the occupants do not get a clear explanation. Such as for the payment collection process, residents Most of the workers seem difficult to take the time to make payments on time. By looking at some of the problems above then made an android-based e-payment information system that can be accessed by residents anytime and anywhere to obtain information about payments and make rental payments. it will be more effective and efficient in delivering information by admin to residents. The system will implement the prototype model to design the system and the system will be designed on an Android platform so that it is easy to use anywhere and anytime.

Keywords: e-payment, prototype model, android

\section{PENDAHULUAN}

Dikarenakan tingkat kepadatan penduduk Jakarta yang sangat padat dan meningkat pesat, banyak dari mereka yang tinggal di tempat yang seharusnya tidak boleh digunakan untuk tempat tinggal, seperti di sepanjang jalur kereta api, pemakaman, tebing tinggi, pinggiran sungai dan lahan-lahan terlantar lainnya. Berdasarkan peraturan gubernur DKI nomor 27 tahun 2009 tentang rumah susun sederhana yang pada saat ini peraturan gubernur tersebut mulai digencarkan kembali, sehingga diperkiraan untuk kedepannya akan semakin banyak masyarakat yang tinggal di rumah susun sederhana tersebut. Salah satu contohnya adalah rumah susun sewa sederhana (Rusunawa). 
Pada saat ini peningkatan akses dalam internet mulai mengubah gaya hidup manusia dalam beberapa aspek, salah satu nya yaitu aspek pembayaran, baik itu pembayaran transaksi jual beli ataupun transaksi pembayaran sewa.

Melihat keadaan sekarang ini Rusunawa masih menggunakan pengolahan data dan penyediaan informasi yang manual, maka perlu dibangun sebuah Sistem Informasi Rusunawa yang dapat memberikan informasi yang up-to-date mengenai informasi khususnya data kamar dan proses pendaftaran yang dapat dilakukan dimana saja dengan menggunakan jaringan internet (Senewe, Sinsuw, Tulenan, \& Karouw, 2015).

Pada jaman dahulu orang-orang melakukan transaksi jual-beli secara langsung dengan tatap muka antara penjual dan pembeli. Saat ini orangorang mulai beralih ke sistem jual-beli secara daring atau dikenal dengan online shopping. Sebagai implikasinya, sistem pembayaran elektronik menjadi hal yang penting(Trihastuti \& Kresna, 2020)

Seiring dengan kemajuan teknologi informasi, praktik pembayaran secara elektronik di kalangan masyarakat semakin meningkat karena menawarkan berbagai kemudahan dan kecepatan dalam melakukan transaksi pembayaran. Pembayaran elektronik adalah pembayaran yang dilaksanakan secara elektronik dimana uang disimpan, diproses, dan diterima dalam bentuk informasi digital dan proses pemindahannya diinisialisasi melalui alat bantu pembayaran elektronik (Marlina, Marzal, \& Mauladi, 2018).

Pada penelitian ini akan dirancang sebuah sistem informasi pembayaran elektronik yang dapat menangani permasalahan pada sistem konvensional dan dapat dengan mudah digunakan oleh para penyewa karena tampilannya dirancang userfriendly.

sistem informasi e-payment pada rumah susun sewa berbasis Android ini merupakan salah satu hal penting yang harus dibangun dan diharapkan dapat bermanfaat karena dapat membantu meningkatkan efisiensi dan keefektifan proses pembayaran dan penagihan sewa serta pemberian informasi yang uptodate pada penghuni rumah susun sewa Kapuk Muara.

\section{LANDASAN TEORI}

\subsection{Pembayaran Elektronik (E-Payment)}

Menurut (Rahardja, Aini, \& Thalia, 2018) Sistem pembayaran pada zaman modern ini sudah banyak diterapkan pada dunia bisnis online. Sistem pembayaran online ini disebut E-Payment, EPayment biasa digunakan pada bisnis E-commerce juga biasa dipakai pada kegiatan pembayaran di tempat yang berbeda dengan jarak yang jauh. Dengan adanya E-Payment, pengguna dengan mudah membayar menggunakan media perbankan online dan melakukan konfirmasi pembayaran langsung pada situs E-Commerce nya.

Ada beberapa model e-payment yang tersedia saat ini diantaranya(Bahri \& Suhada, 2016):

a. Kartu seperti kartu kredit, kartu debit dan kartu prabayar memanfaatkan media kartu berbahan platik dan sebuah magnetik strip, pemegang kartu akan menngesekan kartu ke terminal lalu terminal menstransmisikan data ke pihak bank untuk dilkukan pencocokan akun dan melakukan pembayaran.

b. Internet Model e-payment dengan menggunakan internet yaitu dengan cara user melakukan transfer melalui pihak ketiga untuk dihubungkan ke bank.

c. Mobile Payment Konsumen dapat melakukan transaksi pembayaran dengan cara mengirimkan SMS melalui protokol WAP

d. Biometric Payment Pembayaran dengan teknologi biometrik yaitu pembayaran yang dilakukan dengan memindai retina atu sidik jari konsumen yang bertujuan menggantikan kartu plastik sehingga transaksi menjadi lebih aman.

Kelebihan dari e-payment yaitu sebagai berikut (Muzayyanah, Darmawan, \& Ali, 2016) :

a. Lebih cepat dalam melakukan transaksi pembayaran.

b. Pilihan produk layanan dapat terus di tigkatkan

c. Lebih efektif dan efesiensi waktu

d. Memberikan keamanan dalam bertransaksi 


\subsection{Android}

Android adalah sistem operasi yang berbasis Linux untuk telepon seluler seperti telepon pintar dan komputer tablet. Android menyediakan platform terbuka bagi para pengembang untuk menciptakan aplikasi mereka sendiri untuk digunakan oleh bermacam peranti bergerak. Awalnya, Google Inc. membeli Android Inc., pendatang baru yang membuat peranti lunak untuk ponsel. Kemudian untuk mengembangkan Android, dibentuklah Open Handset Alliance, konsorsium dari 34 perusahaan peranti keras, peranti lunak, dan telekomunikasi, termasuk Google, HTC, Intel, Motorola, Qualcomm, T-Mobile, dan Nvidia (Listyorini \& Widodo, 2013).

Android adalah platform open source yang komprehensif dan dirancang untuk mobile devices. Dikatakan komprehensif karena Android menyediakan semua tools dan frameworks yang lengkap untuk pengembangan aplikasi pada suatu mobile device. Sistem Android menggunakan database untuk menyimpan informasi penting yang diperlukan agar tetap tersimpan meskipun device dimatikan(Silvia, Haritman, \& Muladi, 2014).

Android Development Tool (ADT) adalah plugin yang didesign untuk eclipse IDE yang memberikan kita kemudahan dalam mengembangkan aplikasi android dengan menggunakan eclipse IDE. Dengan menggunakan Android Development Tool (ADT) untuk eclipse akan memudahkan kita dalam membuat aplikasi project android, membuat User Interface (UI) dan menambahkan komponen-komponen lainnya. Begitu juga kita dapat melakukan running aplikasi menggunakan android SDK melalui eclipse. Dengan Android Development Tool (ADT) kita juga dapat melakukan pembuatan package android (.apk) yang digunakan untuk distribusi aplikasi android yang kita rancang.Android Development Tool $(A D T)$ dapat didownload secara gratis(Muzayyanah et al., 2016).

\section{METODE PENELITIAN}

\subsection{Teknik Pengumpulan Data}

Teknik pengumpulan data yang digunakan dalam penelitian ini adalah:

\section{a. Observasi}

Mengamati langsung keadaan rumah susun kapuk muara baik dari segi tempat, pengelolaan maupun penghuni rusunawa kapuk muara. b. Wawancara

Melakukan tanya jawab langsung kepada kepala pengelola rumah susun sewa kapuk muara dan penghuni rumah susun yang berkaitan dengan masalah yang akan dipecahkan sehingga mendapatkan data-data yang benar dan akurat

c. Studi Pustaka

Mengumpulkan sumber referensi kepustakaan berupa buku-buku dan jurnal-jurnal nasional guna mendukung penulisan laporan penelitian ini.

\subsection{Prototype Model}

sebuah Prototyping bagi pengembang sistem bertujuan untuk mengumpulkan informasi dari pengguna sehingga pengguna dapat berinteraksi dengan model prototype yang dikembangkan, sebab prototype menggambarkan versi awal dari sistem untuk kelanjutan sistem sesungguhnya yang lebih besar(Purnomo, 2017).

Menurut (Wijaya, 2019) Model prototype merupakan metode pengembangan sistem dimana hasil analisa perbagian sistem langsung diterapkan kedalam sebuah model tanpa menunggu seluruh sistem selesai.

Metode prototyping yang digunakan di dalam penelitian ini bertujuan untuk mendapatkan gambaran aplikasi yang akan dibangun melalui rancangan aplikasi prototype terlebih dahulu kemudian akan dievaluasi oleh user. Aplikasi prototype yang telah dievaluasi oleh user selanjutnya akan dijadikan acuan untuk membuat aplikasi(Nugraha \& Syarif, 2018).

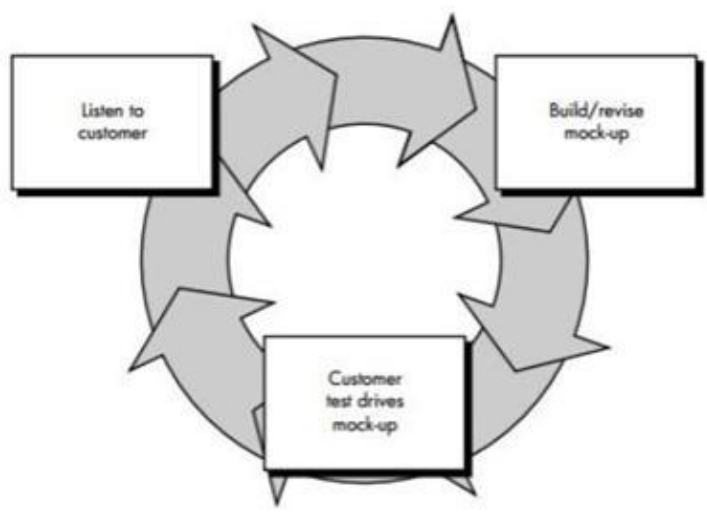

Gambar 1. Tahapan Model Prototype Khosrow-Pour dalam (Wijaya, 2019) 
a. Listen To Customer

Pada Tahapan ini pengembang sistem akan melakukan analisis kebutuhan-kebutuhan guna pengembangan sistem, data -data yang diambil dapat berupa data user pengguna, data transaksi dan laporan dari sistem berjalan. Serta membuat rancangan awal sistem informasinya.

b. Build Mockup

Pada Tahapan ini pengembang sistem akan membangun tampilan awal dari sistem sesuai dengan yang telah dianalisa pada tahap awal. Mockup yang dibuat nantinya sudah mewakili tampilan sistem secara keseluruhan.

c. Customer test drives mockup
Pengembang sistem akan menyerahkan mockup yang telah dirancang kepada Customer untuk dilakukan test terhadap mockup yang telah dibuat dan berdiskusi apakah akan ada perubahan desain atau penambahan sistem.

\section{HASIL DAN PEMBAHASAN}

Berdasarkan hasil analisa tentang kebutuhankebutuhan yang diperlukan, maka dapat diidentifikasikan serta diimplementasikan melalui rancangan sistem, Rancangan Basisdata serta rancangan mockup dari sistem yang dibangun.

\subsection{Rancangan Sistem Informasi}

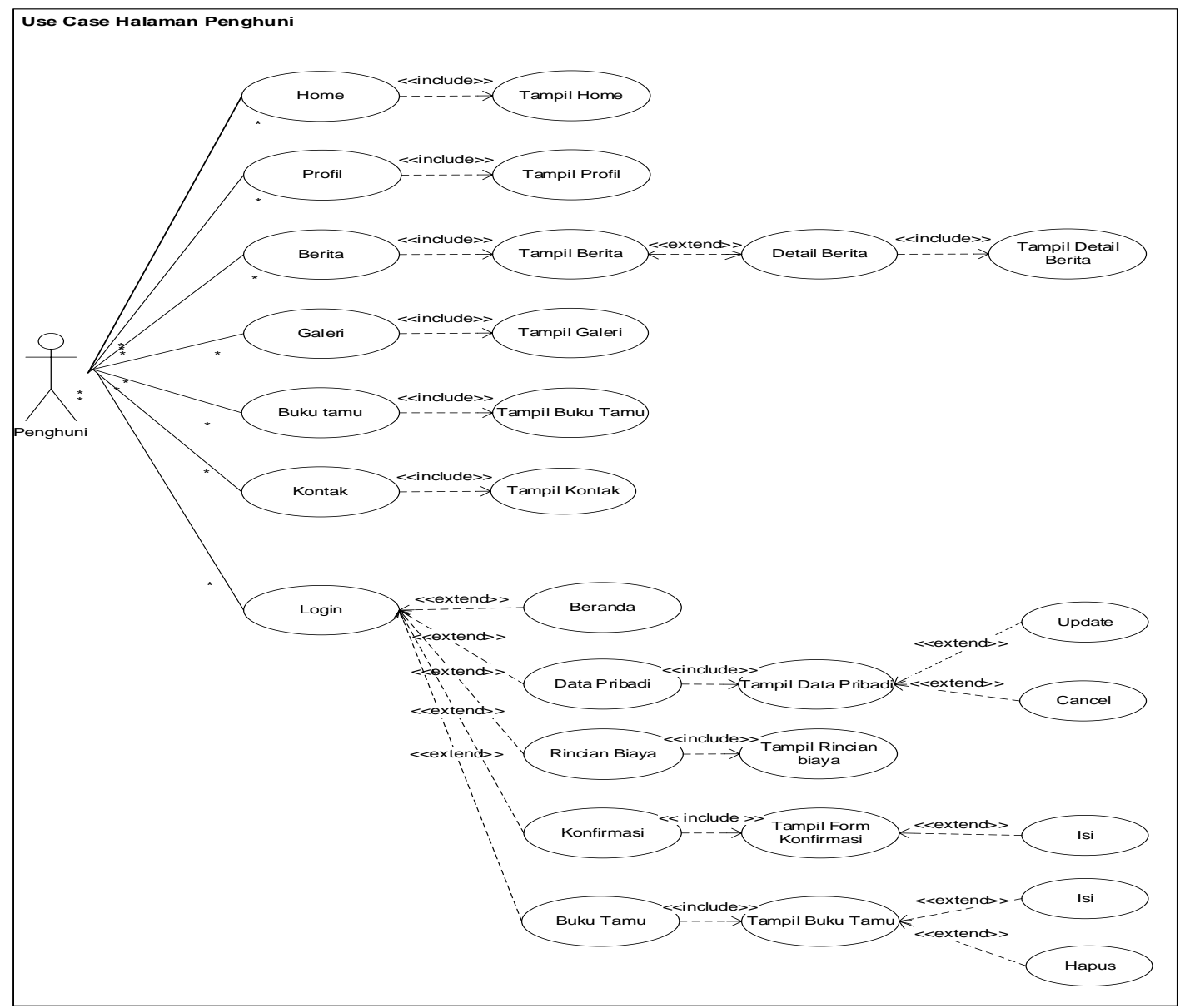

Gambar 2. Usecase Diagram halaman penghuni 


\section{Tabel 1. Deskripsi Use Case Diagram halaman penghuni}

\begin{tabular}{|c|c|}
\hline $\begin{array}{l}\text { Use Case } \\
\text { Diagram }\end{array}$ & Deskripsi \\
\hline Requirement & $\mathrm{A} 1, \mathrm{~A} 2, \mathrm{~A} 4, \mathrm{~A} 5, \mathrm{~A} 6$ \\
\hline Goal & $\begin{array}{l}\text { Penghuni dapat melihat informasi halaman } \\
\text { profil, galeri, buku tamu dan kontak. }\end{array}$ \\
\hline Pre-conditions & $\begin{array}{l}\text { Penghuni memilih menu profil, galeri, } \\
\text { buku tamu dan kontak. }\end{array}$ \\
\hline Post-conditions & $\begin{array}{l}\text { Penghuni mengetahui informasi profil, } \\
\text { berita, galeri, buku tamu dan kontak. }\end{array}$ \\
\hline $\begin{array}{l}\text { Failed end } \\
\text { Condition }\end{array}$ & Data informasi tidak tampil. \\
\hline Primary Actor & Penghuni \\
\hline \multirow{3}{*}{$\begin{array}{l}\text { Main } \\
\text { Flow/Basic } \\
\text { Path }\end{array}$} & 1.Penghuni Membuka alamat website \\
\hline & 2. Penghuni memilih menu profil. \\
\hline & 3.Sistem menampilkan halaman profil. \\
\hline \multirow[t]{3}{*}{ Invariant } & 2a. Penghuni Memilih menu galeri \\
\hline & 2b. Penghuni Memilih menu buku tamu \\
\hline & 2c. Penghuni Memilih menu kontak \\
\hline
\end{tabular}

Tabel 2. Deskripsi Rancangan Use Case Diagram Mengelola Laporan pembayaran

\begin{tabular}{ll}
\hline Use Case Diagram & Deskripsi \\
\hline Requirement & B13 \\
Goal & Admin dapat mencetak laporan \\
Pre-conditions & Admin telah login \\
Post-conditions & Tampil laporan, dan cetak \\
Failed end Condition & Gagal tampil \\
Primary Actor & Administrator \\
Main Flow/Basic Path & $\begin{array}{l}\text { 1. Admin klik data laporan } \\
\text { perpenghuni }\end{array}$ \\
& $\begin{array}{l}\text { 2. Admin memilih nama penghuni } \\
\text { dan id }\end{array}$ \\
& $\begin{array}{l}\text { 3.Submit } \\
\text { 2a. Admin memilih data perido } \\
\text { awal sampai akhir } \\
\text { 3a. Submit }\end{array}$ \\
Alternate & \\
\hline Flow/Invariant 1 &
\end{tabular}

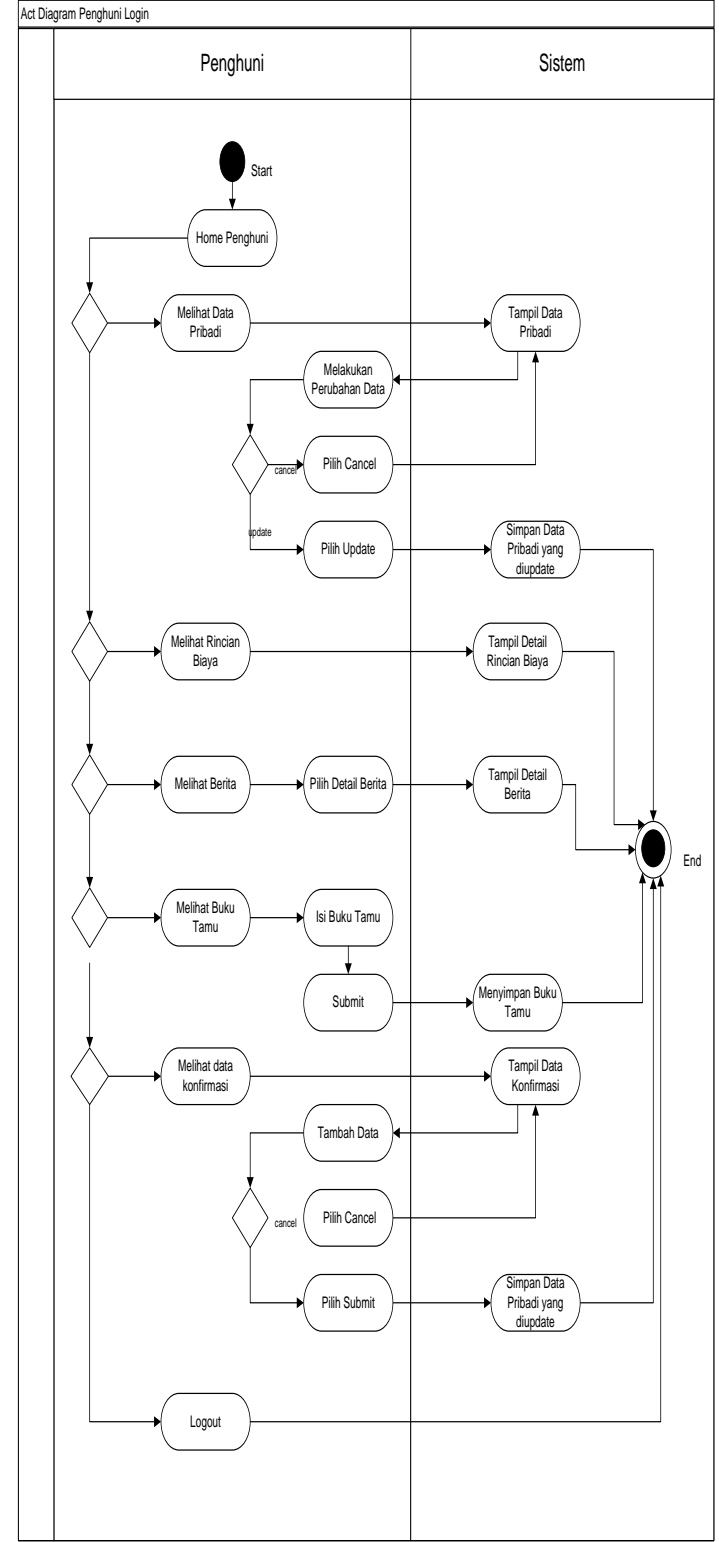

Gambar 3. Activity Diagram User Penghuni

User penghuni akan melakukan login terlebih dahulu untuk dapat melihat Rincian data pembayaran, jika user ingin melakukan proses pembayaran user akan mendapatkan kode pembayaran dan melakukan konfirmasi atas pembayaran yang telah dengan memilih menu konfirmasi yang akan menampilkan form konfirmasi pembayaran nya. Setelah itu admin dapat mencetak laporan pembayaran rusunawa. 


\subsection{Rancangan Basis Data}

Rancangan Basis Data terdiri dari rancangan Entity Relationship Diagram (ERD) dan Logical Record Struktur (LRS)

\section{a. Entity Relationship Diagram (ERD)}

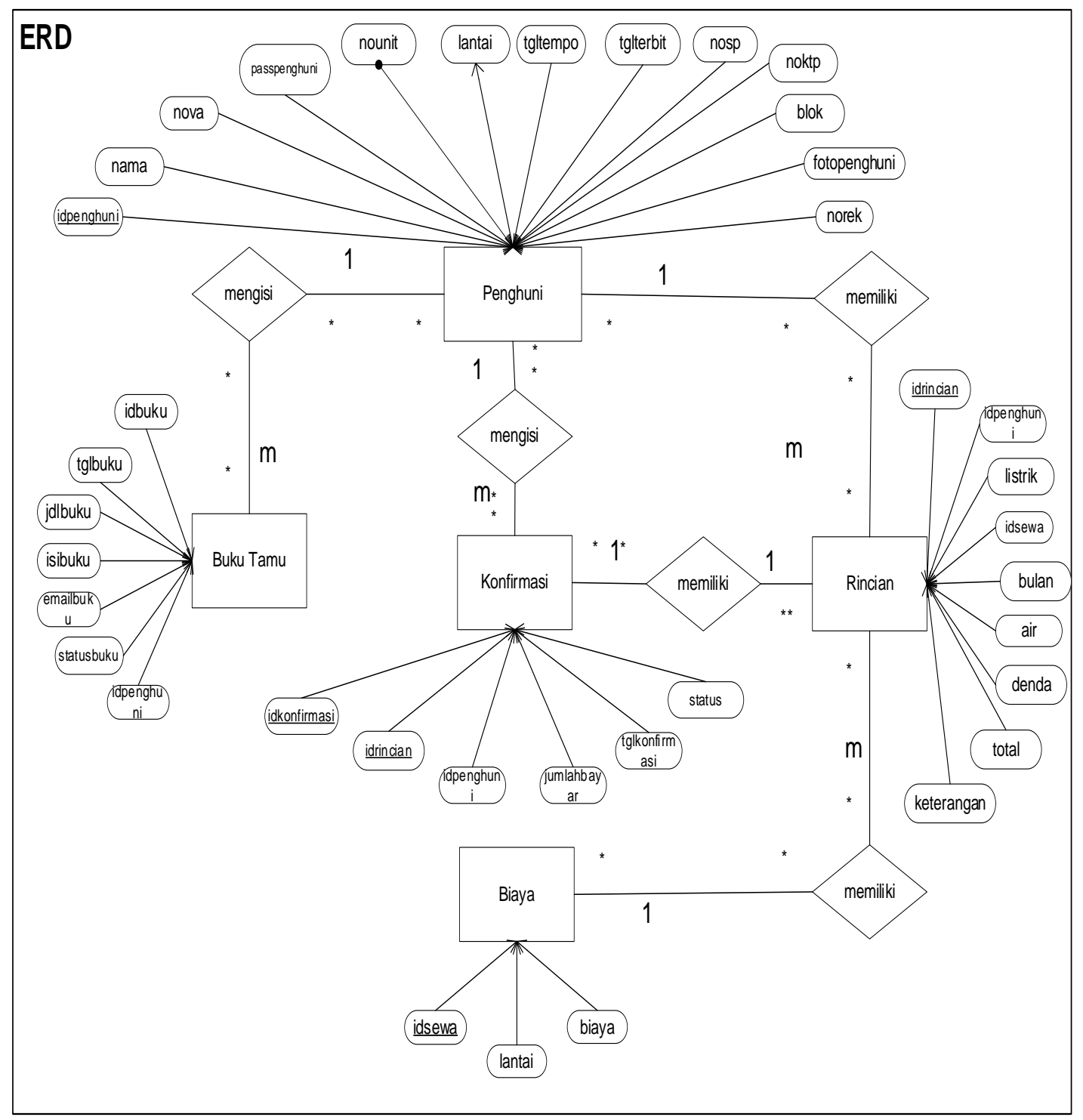

Gambar 4. Rancangan Entity Relationship Diagram 


\section{b. Logical Record Stucture (LRS)}

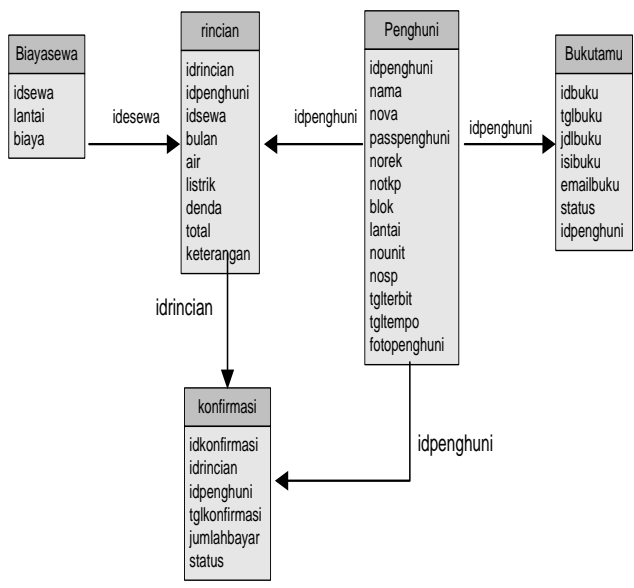

Gambar 5. Rancangan Logical Record Structure

\subsection{Rancangan Mockup Sistem}

Tahapan Ini akan dirancang mockup dari sistem informasi E-payment berbasis Android menggunakan Software Balsamic Mockup.

\section{a. Rancangan Mockup Menu Utama}

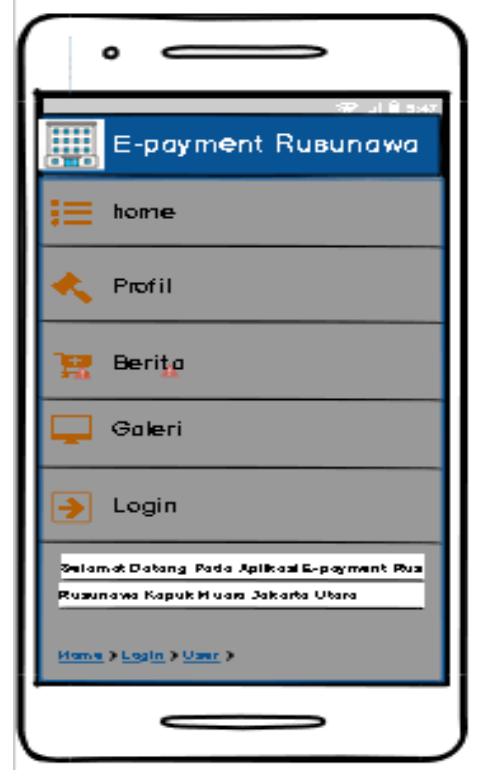

Gambar 6. Rancangan Menu Utama b. Rancangan Mockup Menu User

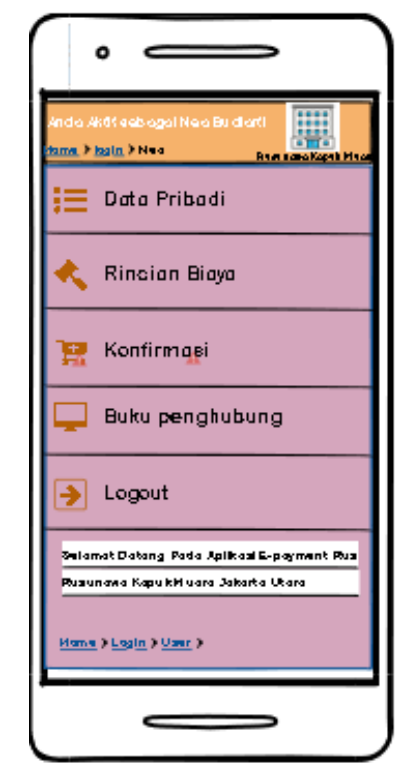

Gambar 7. Rancangan Menu User

c. Rancangan Mockup Rincian Pembayaran

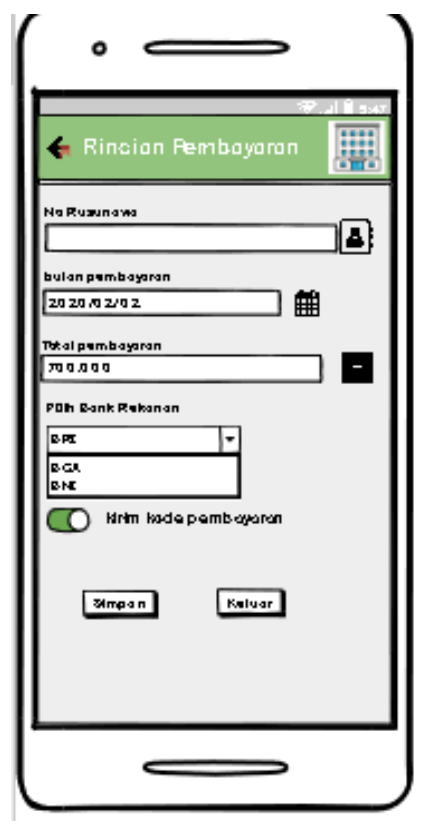

Gambar 8. Rancangan Menu Rincian Pembayaran 


\section{d. Rancangan Mockup Konfirmasi Pembayaran}

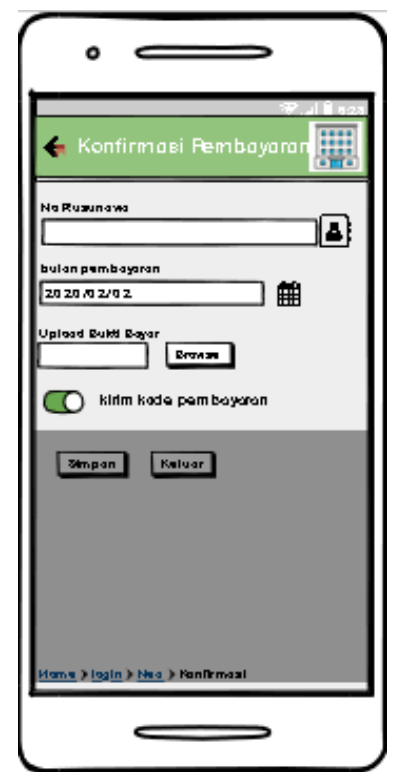

Gambar 9. Rancangan Konfirmasi Pembayaran

e. Rancangan Mockup Laporan Pembayaran

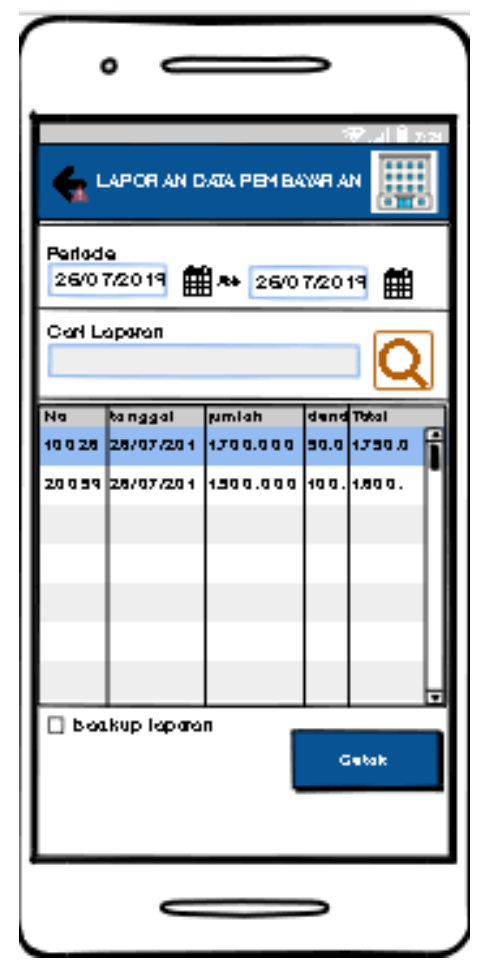

Gambar 10. Rancangan Laporan pembayaran

\section{KESIMPULAN DAN SARAN}

Berdasarkan Uraian Pemecahan masalah dan perancangan sistem Informasi E-Payment Rusunawa ini dapat ditarik kesimpulan sebagai berikut:

1. Dengan Dirancangnya sistem informasi epayment pada rusunawa ini diharapkan dapat memecahkan masalah terkendalanya informasi yang akan disampaikan kepada penghuni rusunawa.

2. Sistem berbasis android ini diharapkan mengatasi masalah pembayaran konvensional sehingga meminimalisir pembayaran yang tidak tepat waktu.

\section{DAFTAR PUSTAKA}

Bahri, S., \& Suhada, S. (2016). PENERAPAN SISTEM PEMBAYARAN SECARA ELEKTRONIK PADA POINT OF SALES ( $\mathrm{P}$. O . S ) BERBASIS NEAR FIELD COMMUNICATION ( NFC ) Seminar Nasional Ilmu Pengetahuan dan Teknologi Komputer Nusa Mandiri. Sniptek, 258-262.

Listyorini, T., \& Widodo, A. (2013). PERANCANGAN MOBILE LEARNING MATA KULIAH SISTEM OPERASI BERBASIS ANDROID. Jurnal SIMETRIS, $3(1), 25-30$.

Marlina, L., Marzal, J., \& Mauladi. (2018). Rancang Bangun Dan Evaluasi Sistem Informasi Pembayaran Elektronik Pada Univeeritas Jambi. Junal Sains Dan Sistem Informasi, 1(1), 5-12.

Muzayyanah, Darmawan, A. K., \& Ali, I. (2016). Rancangan Sistem Informasi E-Payment Berbasis Android. Seminar Nasional Humaniora \& Aplikasi Teknologi Informasi 2016 (SEHATI 2016), 16-17.

Nugraha, W., \& Syarif, M. (2018). Penerapan Metode Prototype Dalam Perancangan Sistem Informasi Penghitungan Volume Dan Cost Penjualan Minuman Berbasis Website. JUSIM (Jurnal Sistem Informasi Musirawas), $3(2)$, 94-101. https://doi.org/10.32767/jusim.v3i2.331

Purnomo, D. (2017). Model Prototyping Pada Pengembangan Sistem Informasi. $J$ I $M P$ Jurnal Informatika Merdeka Pasuruan, 2(2), 54-61. https://doi.org/10.37438/jimp.v2i2.67

Rahardja, U., Aini, Q., \& Thalia, M. B. (2018). 
Penerapan Menu Konfirmasi Pembayaran Online Berbasis Yii pada Perguruan Tinggi. Creative Information Technology Journal, 4(3), 174. https://doi.org/10.24076/citec.2017v4i3.108

Senewe, J., Sinsuw, A., Tulenan, V., \& Karouw, S. (2015). Sistem Informasi Berbasis Web Studi kasus Rusunawa. E-Journal Teknik Elektro Dan Komputer, 4(5), 57-64.

Silvia, A. F., Haritman, E., \& Muladi, Y. (2014). RANCANG BANGUN AKSES KONTROL PINTU GERBANG BERBASIS ARDUINO DAN ANDROID. Electrans, 13(1), 1-10.

Trihastuti, Y., \& Kresna, I. (2020). Metode Pembayaran Elektronik yang Aman pada Online Shopping. Rekayasa Sistem Dan Teknologi Informasi (RESTI), 1(10), 319328.

Wijaya, K. (2019). Rancang Bangun Sistem Informasi Perpustakaan. Jurnal SISFOKOM, 08(1), 53-60. 